Int. J. Dev. Biol. 56: 719-728 (2012)

doi: 10.1387/ijdb.120021rw

\title{
Roles of EphB3/ephrin-B1 in feather morphogenesis
}

\author{
SANONG SUKSAWEANG ${ }^{1,3}$, TING-XIN JIANG ${ }^{1}$, PAUL ROYBAL $^{2}$, \\ CHENG-MING CHUONG*,1 and RANDALL WIDELITZ*,1 \\ ${ }^{1}$ Department of Pathology, ${ }^{2}$ Department of Biochemistry, Keck School of Medicine, University of Southern California, \\ Los Angeles, CA, USA and ${ }^{3}$ Department of Pathology and Laboratory Medicine, Institute of Medicine, Suranaree \\ University of Technology, Nakhon Ratchasima, Thailand
}

\begin{abstract}
The ephrin receptor (Eph) tyrosine kinases and their ephrin ligands are involved in morphogenesis during organ formation. We studied their role in feather morphogenesis, focusing on ephrin-B1 and its receptor EphB3. Early in feather development, ephrin-B1 mRNA and protein were found to be expressed in the dermal condensation, but not in the inter-bud mesenchyme. Later, in feather buds, expression was found in both the epithelium and mesenchyme. In the feather follicle, ephrin-B1 protein expression was found to be enriched in the feather filament epithelium and in the marginal plate which sets the boundary between the barb ridges. EphB3 mRNA was also expressed in epithelia. In the feather bud, its expression was restricted to the posterior bud. In the follicle, its expression formed a circle at the bud base which may set the boundary between bud and inter-bud domains. Perturbation with ephrin-B1/Fc altered feather primordia segregation and feather bud elongation. Analyses revealed that ephrin-B1/Fc caused three types of changes: blurred placode boundaries with loose dermal condensations, incomplete follicle invagination with less compact dermal papillae, and aberrant barb ridge patterning in feather filament morphogenesis. Thus, while ephrin-B1 suppression does not inhibit the initial emergence of a new epithelial domain, Eph/ephrin-B1 interaction is required for its proper completion. Consequently, we propose that interaction between ephrin-B1 and its receptor is involved in boundary stabilization during feather morphogenesis.
\end{abstract}

KEY WORDS: skin appendage development, boundary formation, border formation

\section{Introduction}

During feather morphogenesis, a succession of new domains is generated through interactions between epithelial and mesenchymal cells or among epithelial cells, leading to the building of complex feather forms. Many signaling molecules are involved during feather bud initiation but there is a paucity of evidence pertaining to the regulation of boundary formation for an organ like the feather. At initiation stage, the feather field is composed of $\beta$-catenin positive competent epithelium and homogeneously distributed NCAM positive mesenchyme (Jiang et al., 1999; Noramly et al., 1999; Widelitz et al., 2000). Reaction-diffusion, involving FGF and BMP as respective activators and inhibitors, leads to the periodic arrangement of feather primordia consisting of dermal condensations and epithelial placodes (Widelitz et al., 1996; Jung et al., 1998; Jiang et al., 1999). This process leads to the segregation of the epidermal stem/progenitor cells into the placode and inter-placode epidermal domains, each favored by FGF (Mandler and Neubuser, 2004; Lin et al., 2009) and EGF (Atit et al., 2003) signaling. Committed epithelial cells stop proliferating and become columnar in shape (Fig. 2A,H,E) (Wessells, 1965). Careful analyses showed that the process of periodic patterning involves competitive equilibrium: cells initially can migrate reversibly in and out of the feather primordia domains (Serras et al., 1993; Jiang et al., 1999). The formation of a boundary between the bud and interbud regions does not occur in a single event. Rather, gradual inter-mixing reduces as feather morphogenesis proceeds and the primordia become established. Indeed we have noticed that at very early stages of skin development (E6.5) forming feather primordia have a diameter of $\sim 250$ um but quickly become consolidated to a diameter of $\sim 200$ um. Using chicken skin explant cultures, Notch

Abbreviations used in this paper: Eph, ephrin receptor; Fc, crystallizable fragment of antibody; FGF, fibroblast growth factor.

\footnotetext{
*Address correspondence to: Randall Widelitz. Department of Pathology, Univ. Southern California, Keck School of Medicine, HMR 305D, 2011 Zonal Ave LosAngeles, CA 90033, USA.Tel:+1-323-442-1158. Fax:+1-323-442-3049. e-mail: widelitz@ usc.edu or Cheng-Ming Chuong. Department of Pathology, Univ. Southern California, Keck School of Medicine, HMR 313B, 2011 Zonal Ave, Los Angeles, CA 90033, USA. Fax: +1-323-442-3049. e-mail: cmchuong@usc.edu
} 
interactions with $\beta 1$-integrin were found to play a role in dermal condensation stabilization (Michon et al., 2007) which may account for this consolidation. Furthermore, in motor neurons inhibition of FGF by localized ephrin-Eph signaling specifies posterior neuronal determination and activates the Notch pathway at a distant site to specify anterior neuronal determination (Stolfi et al., 2011). In the homeostasis of intestinal villi stem cells, Notch induced the expression of ephrinB1 but suppressed EphB2 to establish a finite boundary (Koo et al., 2009). Thus there is crosstalk among FGF/Notch/ephrin signaling networks. The molecules involved in stabilizing feather boundaries remain unknown.

Following the stabilization of feather primordia, a new epidermal domain is generated between the bud and interbud domain. This new domain invaginates into the dermis, leading to the formation of a feather follicle, a critical property of skin appendages (Chuong and Homberger, 2003; Maderson, 2004; Jiang et al., 2011). Subsequently, the apparently homogenous feather filament cylinder starts to generate periodically arranged barb ridges (Prum, 1999; Harris et al., 2002; Yu et al., 2002; Chuong, 2003). They form alternatively arranged growth and apoptotic epidermal domains, leading to the formation of feather branches with intervening space (Chang et al., 2004b). Thus, the epidermis is transformed from a two-dimensional sheet into a complex three-dimensional structure. During this process, new domains emerge, become established, and take on different differentiation fates (Chang et al., 2004a; Alibardi and Toni, 2008; Alibardi, 2010a; Alibardi, 2010b). Failure to segregate these domains leads to inter-mixing of cell types and improper morphogenesis. While we have learned that molecules such as FGFs, BMPs and Wnts (Noramly and Morgan, 1998; Noramly et al., 1999; Widelitz et al., 2000; Harris et al., 2004; Jiang et al., 2004) are involved in the initiation of feather buds, and Shh is involved in subsequent feather growth (Ting-Berreth and Chuong, 1996a; Yu et al., 2002), we have not learned much about the molecules involved in the segregation of tissue primordia from one another during feather morphogenesis, so-called boundary establishment.

In recent years, the Eph receptor tyrosine kinases and their ephrin ligands have garnered increasing attention due to their dynamic properties. Ephrin ligands and their receptors, Ephs, are cell membrane molecules now widely known to be involved in cell-cell interactions through cell adhesion and repulsion (Patan, 2004). Eph was first identified in an erythropoietin producing hepatocellular carcinoma cell line (Hirai et al., 1987) and belongs to the receptor tyrosine kinase family (Pasquale, 2005). The Eph receptors elicit forward signals and ephrins provide reverse signals (Davy et al., 2004). There are 16 known receptors with 14 found in mammals (Pitulescu and Adams, 2010). As a rule EphA receptors bind to ephrin-A ligands, which are anchored to the membrane through glycosylphosphatidylinositol (GPI) linkage. EphB receptors bind to the transmembrane ephrin-B ligands, (Pasquale, 2005). However, EphA4 receptors also can bind to ephrin-Bs and EphB2 receptors can also bind to ephrin-A5 (Pasquale, 2010). The formation of Eph tetramers is necessary to elicit biological activity (Vearing et al., 2005). Signaling complexity is derived from the composition and signal capabilities of homo- and heterotypic ephrin-Eph clusters (Janes et al., 2012).

The Eph/ephrin interaction was found to play a critical role in the stabilization of organ boundaries by inhibiting cell inter-mixing and communication (Mellitzer et al., 1999; Xu et al., 1999; Dahmann et al., 2011; Batlle and Wilkinson, 2012). It notably functions at separation and convergence during gastrulation (Park et al., 2011), skeletal patterning (Compagni et al., 2003) and developmental patterning (Coulthard et al., 2002). Ephrin-B is involved in repulsion while ephrin-A participates in adhesion (Poliakov et al., 2004). Tissue stabilization, in particular, requires ephrin and its cognate in many organ systems. For example, during calvaria formation, the stabilization of the coronal suture requires ephrinEph signaling involving ephrin-A2, ephrin-A4 and EphA4 (Ting et al., 2009). Skeletal field boundary formation during digit formation is marked by ephrin-B1 (Davy et al., 2004). Ephrin-B2, ephrin-AL1 and EphA4 are expressed during somite boundary formation (Durbin et al., 1998). Ephrins provide positional cues. It is clear that some mutations in Eph/ephrin can cause the mixing of different cell types at different stages rather than forming clean boundaries during cranium formation (Cooke and Moens, 2002). For example, mutations of ephrin-B1 (EFNB1) can cause craniofrontonasal syndrome in humans (Twigg et al., 2004; Passos-Bueno et al., 2008). Mutations in ephrin-A2, ephrin-A4 and EphA4 can cause faulty suture formation and lead to craniosynostosis (Merrill et al., 2006).

In neonatal mouse skin, either mutation of ephrin-B2 or the use of ephrin-A2/Fc or ephrin-B2/Fc which antagonize ephrin-A and ephrin-B signaling, respectively led to increased keratinocyte proliferation (Egawa et al., 2009), (Genander and Frisen, 2010). In contrast injection of neonatal mouse skin with exogenous ephrin-A3 caused a more rapid induction of anagen in hair follicles which led to increased hair follicle density (Yamada et al., 2008). Ephrin-B1 has been found in the hair matrix and also co-localized with stem cells in the hair follicle bulge (Tumbar et al., 2004). However, the function of ephrin/Eph signaling has not been studied during feather morphogenesis, a classical developmental model system. Here we explore the expression of ephrin-B1 and EphB3 in developing embryonic chicken skin and test the function of ephrin-B1 in feather bud - interbud boundary stabilization.

\section{Results}

\section{Expression of Eph receptors and their ephrin ligands during feather morphogenesis}

We examined the expression of mRNAs of several ephrin members during feather morphogenesis, such as ephrin-B1, ephrin-B2, EphB2, EphB3, EphA2, and EphA6. Among them, ephrin-B1 and one of its receptors, EphB3 had strong expression patterns. Ephrin A2 staining was weak. Ephrin-A4 staining was widely distributed. EphA1 was strong throughout the epithelium and also widely dispersed in the mesenchyme beneath feather buds. EphA4 and EphB2 were expressed at the epithelial-mesenchymal interface and were weakly expressed throughout the mesenchyme. EphA2 and $A 6$ staining were much weaker with a generalized expression pattern (data for ephrin-A2, -A4, EphA1, A2, A6, B2 are not shown). For this article, we focused on ephrin-B1 and EphB3 by examining their expression during skin development using whole mount and section in situ hybridization. We also looked at ephrin-B1 expression by immunostaining (antibodies which cross reacted with chicken EphB3 were not available).

At stage 27 (embryonic day 6, E6), ephrin-B1 and EphB3 were completely absent from the skin. At stage 32 (E7.5), ephrin-B1 and EphB3 started to appear as small dots in the center of emerging feather primordia. At stage 34-35 (E8), staining for ephrin-B1 EphB3 intensified within the feather placodes. Interestingly, the expression 
of EphB3 was restricted to the posterior part of the feather (Fig. $1 \mathrm{~A})$. Feather bud development shows a medio-lateral gradient with the most advanced feather buds toward the midline of the dorsal tract and less mature feathers toward the lateral edges. In the spinal tract at stage 36 (E9), feather buds at different developmental stages are visible. Since buds initiate from the midline and then are subsequently laid out bilaterally, buds nearest the midline are oldest and those nearest the lateral edge are less mature. By stage 36 (E9) the ephrin-B1 expression pattern expanded from the center to cover the entire primordia. The expression became accentuated at the border of the placode appearing as a ring. At stage 38 (E10), feather buds elongated and the ephrin-B1 expression domain expanded but remained strong at the base where invagination will occur (Fig. 1B).

Section in situ showed that the ephrin-B1 transcript was positive in the bud domain, but absent in the interbud domains. It was present in both epithelium and mesenchyme with a stronger message in the mesenchyme at the placode stage. By the short bud stage, expression levels within the epithelium and mesenchyme became more equal. The expression receded to the distal mesenchyme and eventually disappears, leaving strong expression in the epidermis at the junction between the bud and interbud domain at the longer bud stage (Fig. 2A).
The expression of ephrin-B1 protein was also detected by immunostaining. The protein expression patterns were similar to that of the transcript. In the short bud stage, ephrin-B1 protein appeared to be higher in the posterior buds. In the feather filament, eprhin-B1 could be seen in the barb ridge epidermis (Fig. 2B). At the tip of the feather, the expression remained high only in the barb ridge epidermis (Fig. $2 \mathrm{~B}$, inset). In the growth phase adult feather follicle ephrin-B1 transcripts were in the epithelium at the base of the follicle and in the barb ridges (Fig. $2 \mathrm{C}$, green, blue and red boxes). Cross sections at the base of the follicle showed that in the rachis (yellow box), ephrin was absent from the basal layer. It was present in the differentiated central pith region of the rachis but absent from the more differentiated cortical layer of the rachis. In the barb ridges (purple box), ephrin-B1 was in the barb plate and the basal epithelial layer (Fig 2C).

The expression of EphB3 was observed with in situ hybridization. It was first expressed in posterior primordia and gradually expanded to appear in a half-moon pattern (Fig. 1A). Section in situ revealed that the expression of ephrin-B1 was limited to the placode epithelium. Later, it became located in the junctional epidermis between the bud and interbud domains (Fig. 2A). In adult feather follicles, EphB3 was present in the epithelium and largely overlapped with ephrin-B1. However, in the rachis, EphB3 was
A

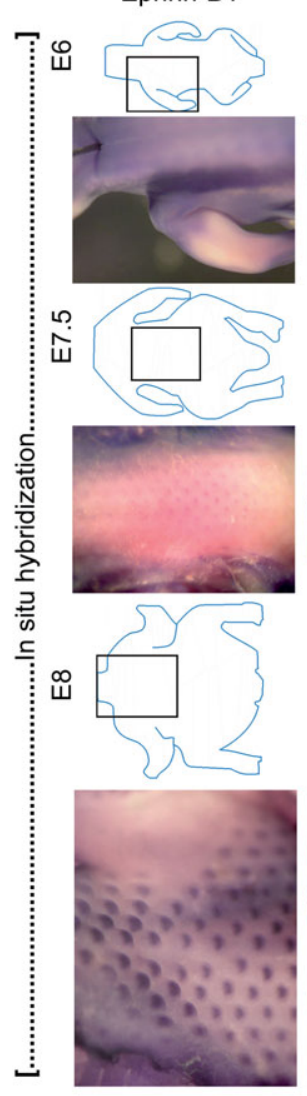

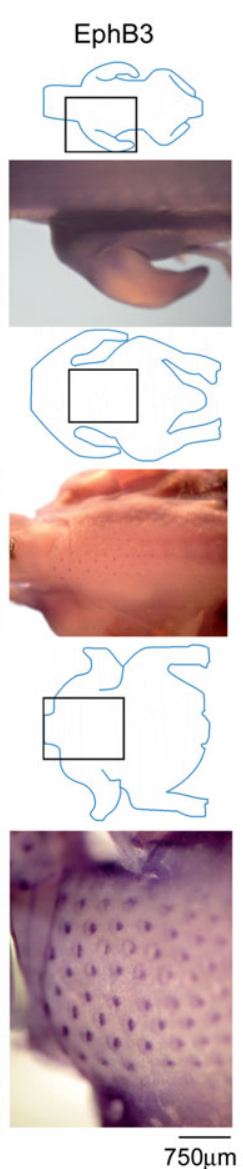

B
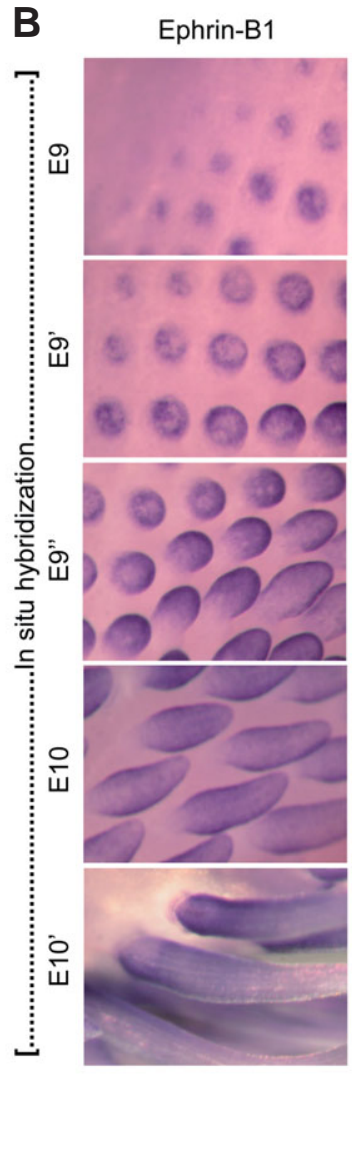

EphB3

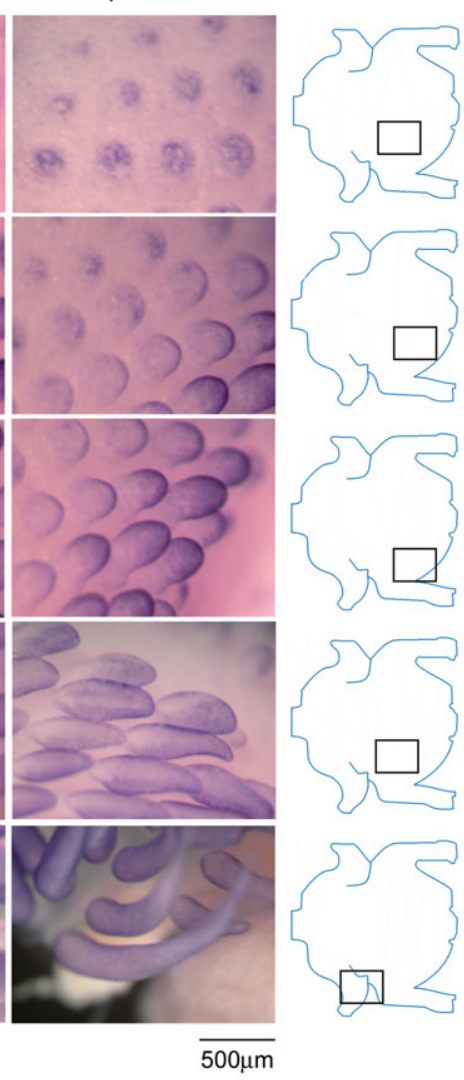

Fig. 1. Expression of ephrin-B1 and EphB3 in feather morphogenesis. (A) The expression patterns of ephrin-B1 and EphB3 were examined during early feather development. Ephrin-B1 and EphB3 were expressed diffusely at $E 6$ but were elevated in regions between feather tracts, suggesting they may be involved in tract formation. Later, at E7.5 they became expressed toward the center of the feather bud gradually diminishing toward the periphery (boundary) of the buds in the dorsal tract. This may be due to the prominent expression of ephrin$B 1$ in mesenchymal cells at the center of the feathers as confirmed by section in situ hybridization. At E8 their expression increased and ephrin-B1 was seen predominantly at the posterior region of the feather bud while EphB3, one of the ephrin$B$ receptors, was restricted to the posterior $(P)$ part of the feather. Size bar, 750 um. (B) Three stages of skin development from E9 embryos and 2 stages from $E 10$ embryos are shown. Progressive stages of skin developmentare shown from the top to the bottom of the figure. The sites where the feather buds are located are shown schematically. Note, these regions are caudal to those shown in Fig. 1A. The top figure represents a region with less mature feather buds (short bud stage). Here ephrin-B1 was in the center of younger feather buds and spread throughout the bud at later stages. As the bud grew, ephrin-B1 expression moved to the periphery at the long bud stage. At the base of the feather where the invagination occurred the expression was in the pattern of a ring surrounding the feather base (far right of E10). Meanwhile, the expression of EphB3 at E9 was in the center of the young feather buds overlapping the expression of ephrin-B1. They then were expressed throughout the bud. Expression then moved to the distal, posterior region of the buds. At E10 a ring of expression near the feather base also appeared. Size bar, $500 \mu$ m. 
A

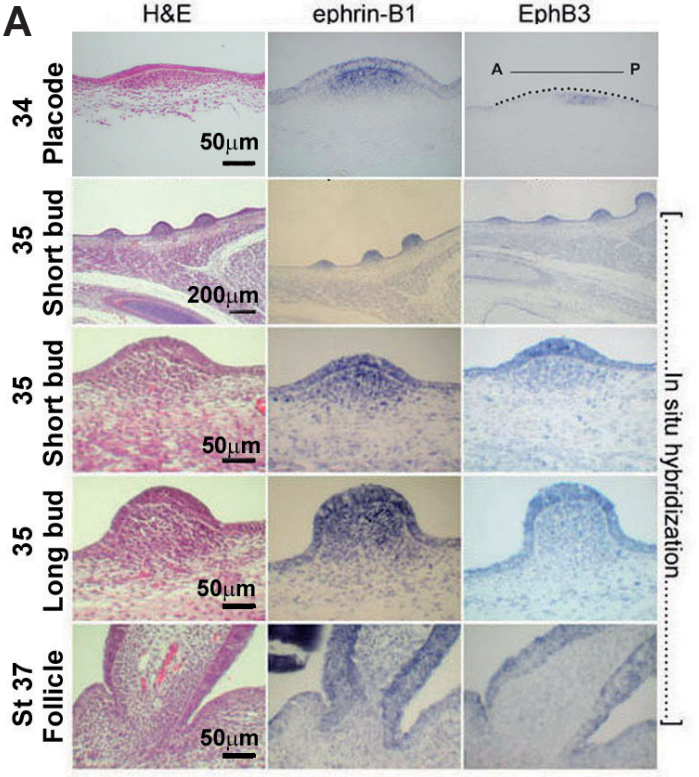

c

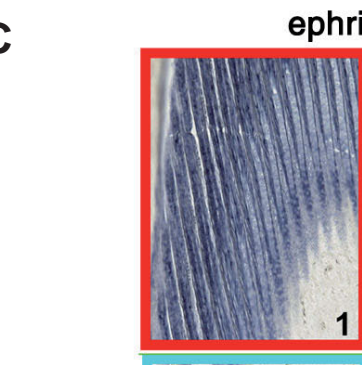

ephrin-B1

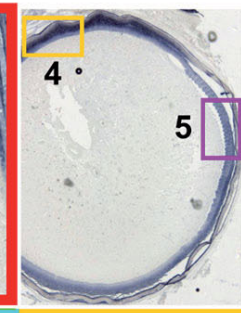

ephrin-B1
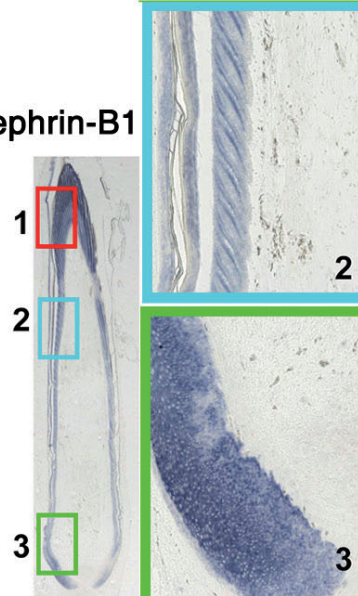

2

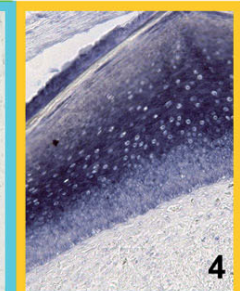

4
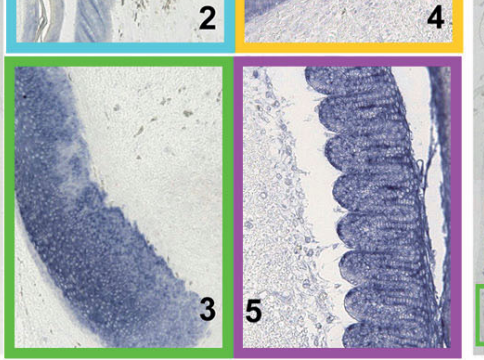

B

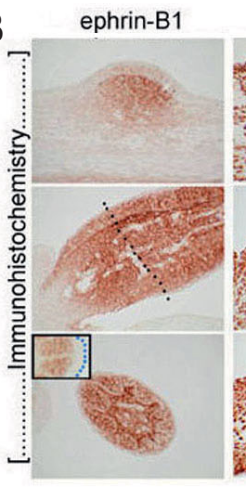

ephrin-A4

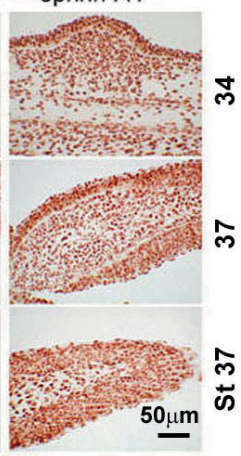

m

$\hat{m}$

ก . ies which bind to chicken EphB3 were not available.

\section{Effects of ephrin-B1/Fc on placode boundary and mesenchymal condensa- tion formation}

During induction of feather primordia, cellular rearrangements take place due to migration and positioning which convert cells in feather fields from a homogenously distributed state to periodically arranged featherprimordia. Each primordium consists of placode epithelium and the underlying dermal condensation. To investigate the possible role of ephrin-B1 in cell arrangements during boundary formation, we added recombinant ephrin-B1 fused to the Fc portion of human IgG to the feather reconstitution assay (Jiang et al., 1999). Ephrin-B1/Fc is soluble and can bind to the Eph receptors promoting only forward signal activation. Hence they block reverse signaling and compete with endogenous ephrins from activating complete bidirectional signaling (Santiago and Erickson, 2002). Feather primordia formation was dramatically affected. Although feather primordia eventually formed, they were wider and less elongated than controls at day 4 in culture (Fig. 3A,A'). The specimens were prepared with whole mount LCAM immunofluorescent staining and viewed by confocal microscopy from below. A ring-like expression pattern was observed around each feather base in control samples. In the ephrin-B1/Fctreated specimens, however, the ring was partially incomplete and/orirregular compared to that of controls (Fig. 3 B, B'). We noticed that at day 2 in culture, feather buds in the control group formed much better with more discrete inner boundaries (Fig. 3C,C', arrow). These matured into smaller inner boundaries at later stages in controls (Fig. 3D) but failed

Fig. 2. Expression of ephrin-B1 and EphB3 during early feather formation and barb ridge formation. (A) H\&E staining of sections representing three different stages of the feather $(A, E 7 ; B$, E8 and C, E10). The MRNA of ephrin-B1 was detected in both the epithelial layer and mesenchymal layer. Ephrin-B1 was expressed stronger in the posterior mesenchyme. EphB3 was also observed predominantly in the epithelial layer at all stages. (B) Ephrin-B1 protein was expressed toward the posterior mesenchyme at the short bud stage. The level of protein was much higher in the mesenchymal cells than the epithelial cells when compared to the transcript. At the feather follicle stage it continued to be expressed in the epithelium and mesenchyme. In barb ridge formation, expression was higher in the basal layer in regions that will become the marginal plate epithelia. (C,C') Expression patterns of ephrin-B1 (panel C) and EphB3 (panel $C^{\prime}$ ) mRNAs in growth phase adult feather follicles. Ephrin-B1 and EphB3 were expressed in epithelial cells of the follicle. They were present in the barb ridges (red/blue boxes numbered 1-2') and at the base of the follicle (green box numbered 3, 3'). Their patterns overlap in the rachis (yellow box numbered 4, 4'). Ephrin-B1 expression was higher than EphB3 in the rachis but ephrin-B1 was limited to the pith epithelium while EphB3 was also present in the cortical epithelium. In the barb ridges (purple box numbered 5, 5'), ephrin-B1 was present in the basal epithelium and the barb plate. EphB3 was absent from these two regions. 
to do so in ephrin-B1/Fc treated cultures (Fig. 3D').

We further examined the behavior of mesenchyme cells and found that mesenchymal condensation occurred with a lower efficiency. This was seen with the help of whole mount immunofluorescent staining for the mesenchyme-specific marker, NCAM. In the control, mesenchymal cells form tight clusters of dermal condensations beneath each placode (Fig. 3 E,E'). On the other hand, in ephrin-B1/ Fc treated specimens, mesenchymal condensations were loosely arranged and much bigger than in controls (Fig. 3 F,F').

\section{Effect of ephrin-B1/Fc on follicle formation}

Tissue sectioning showed that the ephrin-B1/Fc treated feather buds are abnormal. The loosely organized mesenchyme cells led to a broader "foundation" of the feather base with low-density that was close to that of interbud mesenchyme (Fig. 3G; see length of arrows). These feather buds did not elongate like controls. The ring observed in Fig. 3 B,B' was due to invagination of the feather buds that created the feather hinge region. H\&E stained sections showed that this bud-interbud boundary did not form firmly and did not invaginate into the dermis as deep as controls (Fig. $3 \mathrm{H}$ ). The density of mesenchymal cells in treated skin was lower than that found in controls (55 to $66+/-4$ nuclei per field, $n=60$ ). We also observed the unusual multi-layer organization of the epithelial cells (see the propidium iodide and LCAM staining, Fig. 3G).

We characterized the molecular expression of these deranged feather buds further (Fig. $3 \mathrm{H}$ ). Since changes in proliferation were seen in mouse skin with suppressed ephrin activity, we examined proliferation by staining for proliferating cell nuclear antigen (PCNA).

Fig. 3. Effect of ephrin-B1/Fc on dermal condensation formation and follicle invagination. $\left(\mathbf{A}, \mathbf{A}^{\prime}\right)$ Whole-mount view of reconstituted feather growth after 96 hours in the presence $\left(A^{\prime}\right)$ or absence $(A)$ of ephrin-B1/ $F C$. Control feathers elongated with a uniform size and orientation while treated specimens were wider and not consistently oriented. (B, $\left.\mathbf{B}^{\prime}\right)$ The ventral view of LCAM (E-cadherin) staining showd a circular staining at the periphery of the base of the feather bud shape. The control circles were more uniform and smaller than the treated skin. The staining was more diffuse in the ephrin-B1/Fc treated samples. (C,C') Feather bud boundaries observed after 48 hours. Control feather buds had nice definitive boundaries (arrow). However, feather buds in ephrin-B1/Fc treated skin formed more slowly and the boundary had not yet formed. (D,D') Enlargements of the areas indicated in the white boxes in $B, B^{\prime}$, respectively. 96 hrs of incubation. (E,E') NCAM staining of dermal condensations. Control feather buds showed well defined dermal condensations (E). Treated cultures showed more diffuse dermal condensations with the zone of NCAM staining extending beyond the bud boundary into
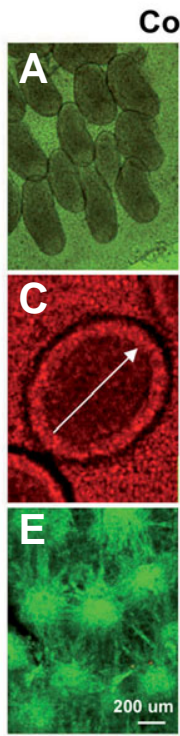

Control
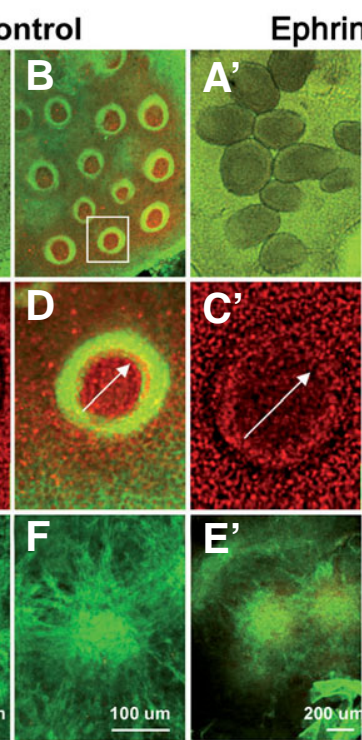

Ephrin-B1/Fc
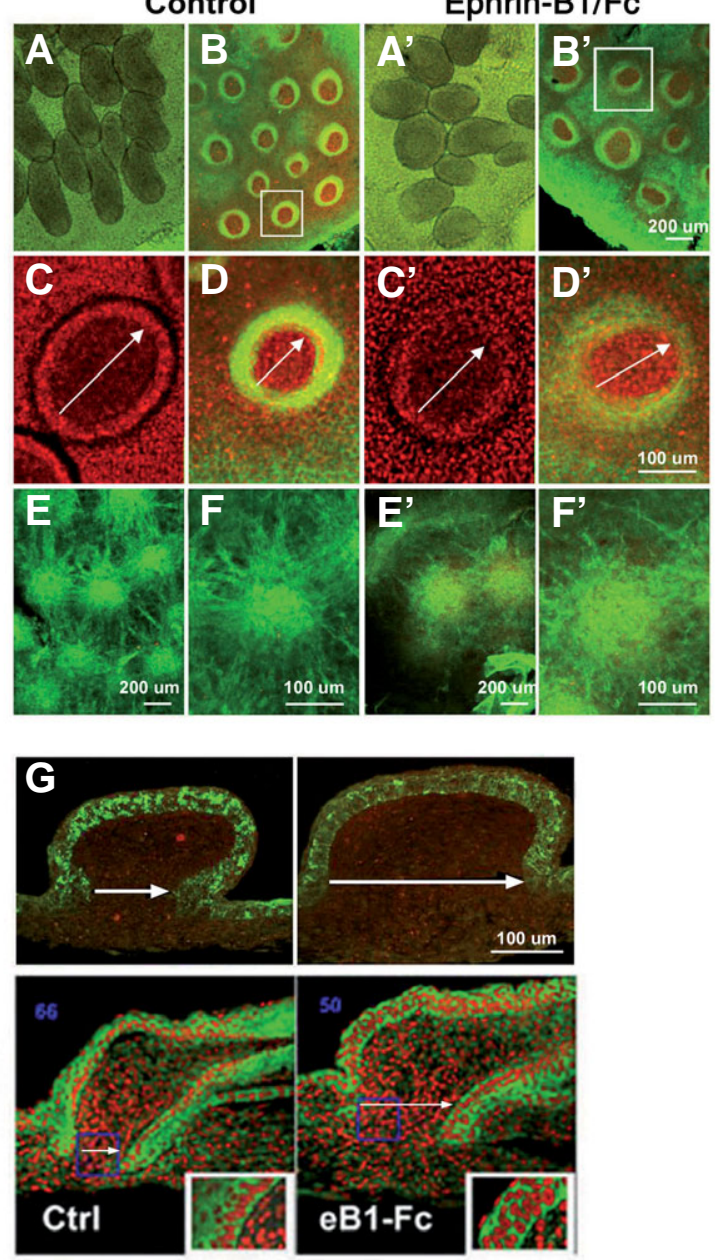

H
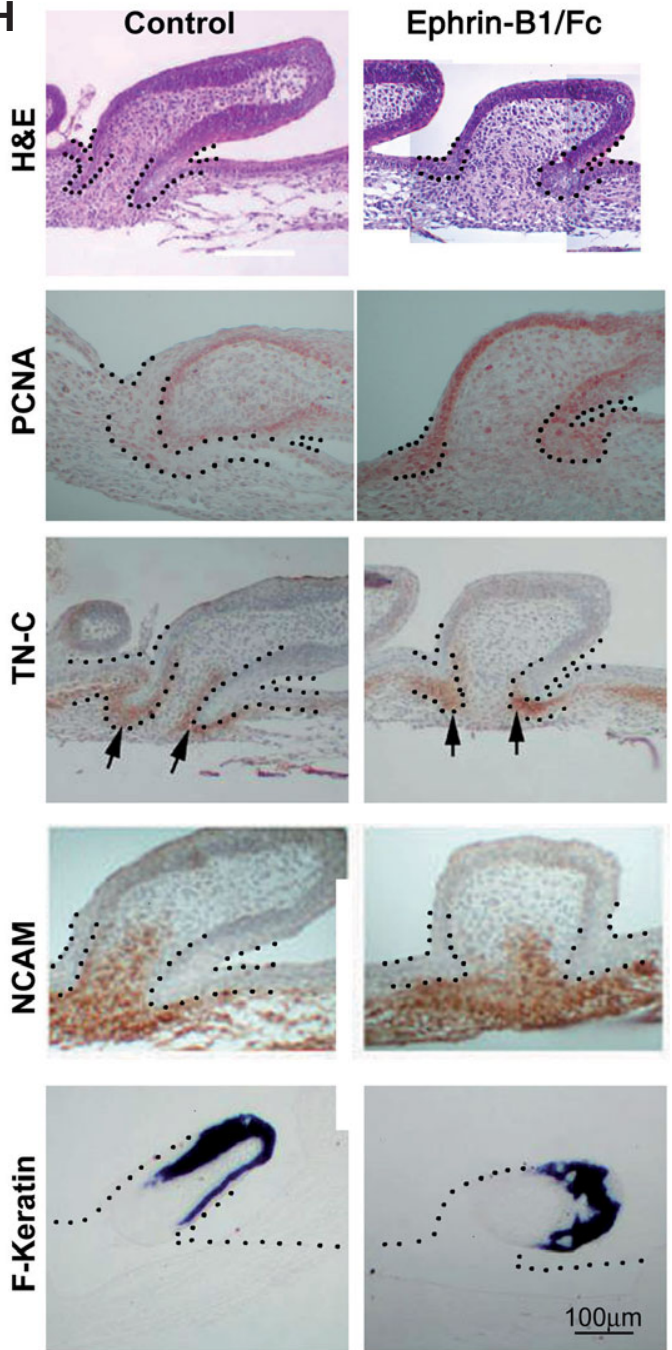
of feather buds 9 days after reconstitution stained for LCAM for control and ephrin-B1/FC treated samples. Treated samples were much broader than controls. Arrows indicate the size of the feather base. LCAM staining was excluded from the basal epithelium of controls but was present in the more differentiated suprabasal layers. In contrast, LCAM staining was excluded from basal as well as suprabasal layers in the treated samples. Size bar, 100 $\mu \mathrm{m}$. (H) H\&E staining of feather buds 9 days after reconstitution. The invagination process was inhibited in ephrin-B1/FC treated skin. Proliferation was increased in the epithelium of feathers treated with ephrin-B1/FC as determined by PCNA staining. Tenascin C (TN-C) was present in the epithelium at sites of invagination in both control and treated skin (arrows); however, the control skin showed a larger region of TN-C expression and deeper invagination. Neural cell adhesion molecules (NCAM) were present at the base of the feather follicle, but the segregation between bud and interbud was not clear in the ephrin-B1/fc treated skin. Feather keratin (F-Keratin) was expressed similarly in control and ephrin-B1/fc treated feathers. Size bar, 100 $\mu$ m. 
Proliferation in control buds is predominantly in the posterior bud epithelium at earlier stages of development and then shifts to the distal bud regions (Chodankar et al., 2003). Proliferation remains strong in the epithelium of ephrin-B1/fc treated chicken skin compared to controls. Tenascin-C (Tn-C) is known to be expressed in the mesenchyme beneath the invaginating epidermis when feather buds grow into feather follicles (Jiang and Chuong, 1992). Tn-C is expressed to much lower levels in ephrin-B1/Fc treated samples. Expression of NCAM spread across the bud-interbud boundary into the neighboring interbud regions in ephrin-B1/Fc treated specimens. While follicle formation is delayed, feather bud epithelia were able to differentiate, expressing feather keratin (F-Keratin).

Invagination of the epithelial sheet involves cell rearrangements. Specimens were stained with propidium iodide and LCAM to help visualize cell arrangements and cell shape changes (Fig. 4). The shape of feather buds was dramatically altered in skin treated with ephrin-B1/Fc. Treated buds failed to elongate and did not invaginate as deeply as control buds $\left(A, A^{\prime}\right)$. Three regions, the bud (B', B'), invagination site (C, C') and interbud (D, D') regions

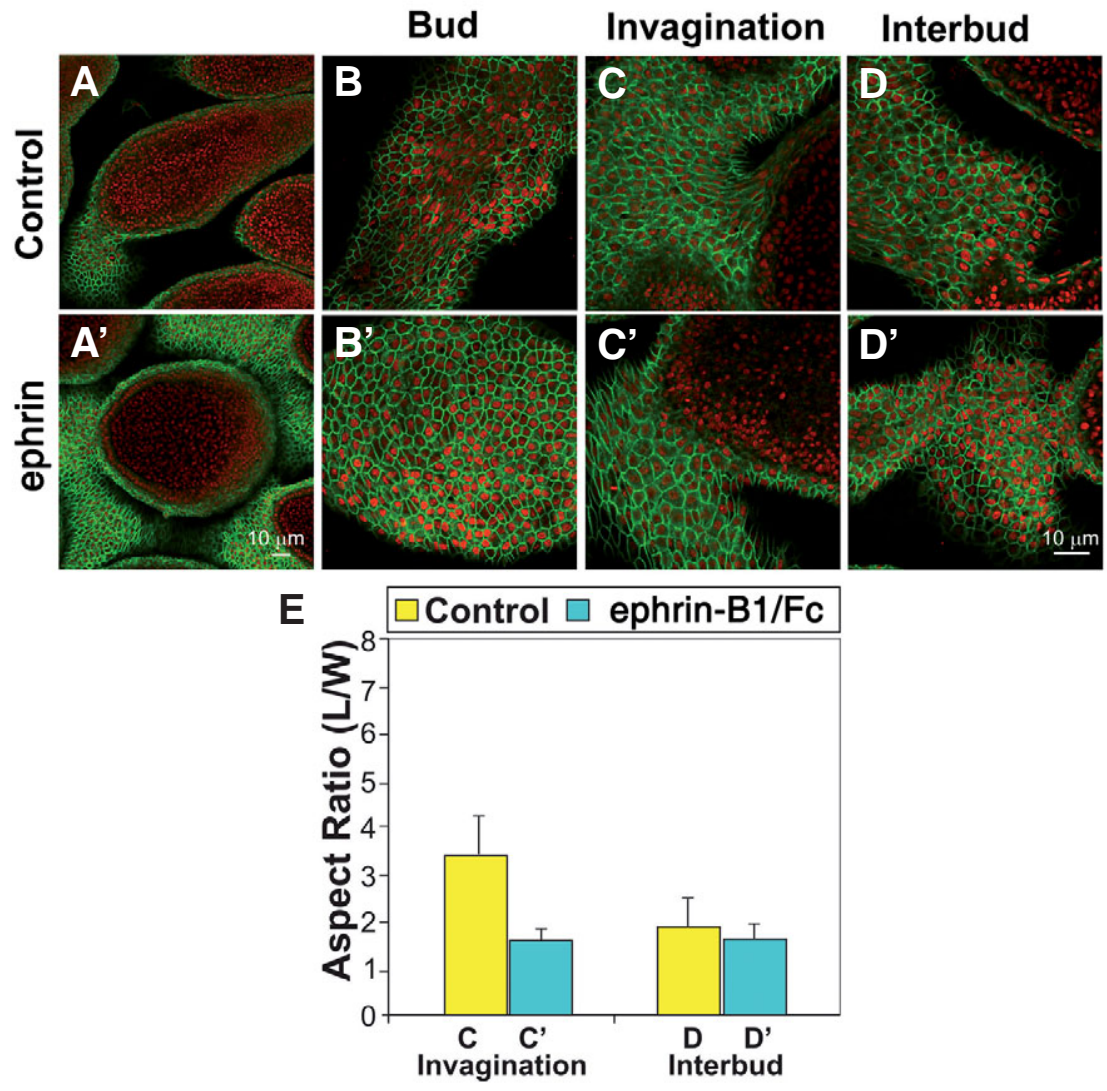

Fig. 4. Effect of ephrin-B1/Fc on epithelial cell shape and arrangement. Control (A-D) and ephrin-B1/Fc treated $\left(\mathbf{A}^{\prime}-\mathbf{D}^{\prime}\right)$ reconstituted skin explants stained for LCAM. The feathers grew from the left side of these panels $\left(\mathbf{A}^{\prime} \mathbf{A}^{\prime}\right)$. LCAM positive epithelium is shown for bud $\left(\mathbf{B}, \mathbf{B}^{\prime}\right)$, invagination site $\left(\mathbf{C}, \mathbf{C}^{\prime}\right)$ and interbud region (D, $\left.\mathbf{D}^{\prime}\right)$. Control feathers formed a more complete feather boundary at 6 days after reconstitution, than the treated samples. Control cells elongated into the base of the feather producing a higher aspect ratio (length/ width) than that seen in the cells from the treated specimens $\left(C, C^{\prime}\right)$. (E) Chart of epithelial cell aspect ratio showed a dramatic difference between the interbud areas in control vs ephrin-B1/Fc treated skin. The bud region did not show significant changes in cell aspect ratio. Data are presented as the average and standard deviation. Size bar, $10 \mu \mathrm{m}$. L, length; $W$, width of each cell. were analyzed. In the bud regions, cell shape varied from rounded elongated and there was not a significant difference between the cellular axis parallel to the proximal-distal axis of the feather (Fig. 4 C,C'). Cells in ephrin-B1/ while others were oriented toward the invagination groove which did not form as deeply (Fig. $4 \mathrm{~A}, \mathrm{C}, \mathrm{A}, \mathrm{C}^{\prime}$ ). In the interbud regions, cells in control and ephrin-B1/Fc treated specimens had a polygonal hape though the size of the ephrin-B1/Fc treated cells was reduced. We quantified changes in cell shape by measuring the aspect ratio (the ratio of cell length and width. A nearly round cell will have an aspect ratio $=1$ and an elongated cell will have a number much the invagination and bud region became higher, reflecting the formation of follicles and elongation of feather buds. The aspect ratio of the interbud region remained the same. In the eprhin-B1/ Fc treated samples, aspect ratios failed to increase (Fig. 4E, $n=90$ ).

\section{Effect of ephrin-B1/Fc on barb ridge formation during feather filament morphogenesis}

Normally, epithelial cells in the stratified epidermis rearrange forming periodical barb ridges, and then keratinocytes within each barb ridge rearrange to form two rows of barbule plates (Fig. 5A). Ephrin-B and EphB3 were present in the rachis and barb ridges of growth phase adult feather follicles (Fig. 2 C,C'). We wondered whether eph/ephrin signaling might play a role during adult feather development. To address this, ephrin-B1/Fc coated beads were implanted into growing feather follicles. We observed changes in barb ridge formation (Fig. 5B). The process of barb ridge formation involved several steps of epithelial cell arrangement (Lucas and Stettenheim, 1972; Chang et al., 2004b). In the sections of feather follicles of ephrin-B1/Fc treated skins, the barb ridges were unevenly formed. Furthermore, barbule plate keratinocytes lost their organization to form a swirl of "keratinocyte pearls" (Fig. 5B). This is consistent with the presence of ephrin-B1 in the barb plate (Fig. 2C).

\section{Discussion}

Members of the Eph/ephrin signaling pathway have been documented in human (EphA1, A2, A4A7, EphB1, B3-B6, ephrin-A1, A3-A5, ephrin-B1-B3; (Hafner etal., 2004) and mouse (EphA1, 3, 4, 6 and 7; EphB3, 4, 6; ephrinA1-A5, ephrin-B1,-B2) (Genander and Frisen, 2010) skin. Ephrin-A2/Fc and ephrin-B1/ Fc blocked eph/ephrin interactions in mouse skin increased proliferation in the hair follicle and basal epithelium of the skin (Genander and Frisen, 2010). The EphA1 receptor is down regulated in human skin cancer (Hafner et al., 2004). A deletion of EphA2 led to the enhanced chemical transformation of mouse keratinocytes (Guo et al., 2006) suggesting Eph/ 
Fig. 5. Effect of ephrin-B1/Fc on barb ridge formation. (A) This schematic diagram shows how cells interact to form barb ridges. At step 3 the growth zone is established. Eph/ephrin signaling seems to act prior to step 4 when the growth zone becomes localized. As a result, barb ridges are of unequal size and irregular in shape. BSA, bovine serum albumen. (B) Feather branching was characterized by the formation of barb ridges within the epithelium. Cells within these structures were organized into forming feather barb ridges. This organization was disrupted in ephrin-B1/FC treated explants. While periodically arranged barb ridges could still differentiate, the perturbed barb ridges lost their consistent organization. Size bar, $100 \mu \mathrm{m}$. In ephrin-B1/FC low magnification panel, size bar, $200 \mu \mathrm{m}$.

ephrin signaling may normally suppress proliferation in the skin. However, Eph/ephrin signaling sometimes has the opposite effect. For example in melanoma cells EphA2 activation increases proliferation (Easty and Bennett, 2000; Hess et al., 2007).

Here, we examined the expression of ephrin-B1 and EphB3 in chicken skin. These molecules follow a de novo mode of expression and appeared within feather primordia after they began to form. We used ephrinB1/Fc which was previously shown to block ephrin-B1 signaling in quail (Santiago and Erickson, 2002), to examine its function in feather morphogenesis. We found that proliferation was increased in the treated feather follicles compared to controls. This is similar to the finding in mice (Genander and Frisen, 2010). Although ephrin signaling induced proliferation, the formation of dermal condensations in chicken skin does not rely on proliferation (Wessells, 1965) but solely on cell migration (Olivera-Martinez et al., 2001; Michon et al., 2007; Lin et al., 2009). Our data show that the chicken feather follicles grew wider rather than elongating after suppression of ephrin signaling. This suggests that the buds failed to form a localized growth zone which also occurs when the $\mathrm{Wnt} / \beta$-catenin pathway is ectopically expressed in developing feather buds (Chodankar et al., 2003). The dermis remained loosely packed suggesting that cell-cell affinity was diminished in the interbud region during cell migration to form dermal condensations which otherwise would have high cell-cell affinity.

We demonstrate for the first time that Eph/ephrin interaction is essential for proper feather morphogenesis, especially in boundary stabilization. When ephrin-B1/Fc was added to the reconstituted feather-formation culture model, early feather patterning proceeded normally through the short bud stage. Molecular and morphological asymmetries began to form similarly to those seen in control feather primordia during early phases of the long bud stage, but shortly afterward, progression of feather morphogenesis became partially halted and deranged. In normal feather bud development a ring of LCAM expression appeared at the site of inner bud boundary formation. This expression became diffuse after ephrin-B1/Fc treatment. Ephrin-B1/Fc treated skin remained abnormal at molecular, cellular and morphological levels throughout subsequent developmental stages. We observed 1) dramatically altered dermal condensations, 2) incomplete

invagination, 3) disrupted elongation and 4) uneven segregation during barb ridge formation (Fig. 6). Therefore, our results show that the Eph/ephrin signaling pathway is involved in proper feather development, especially in the stabilization of feather boundaries.

Although feathers that formed after ephrin-B1/Fc treatment were abnormal, the feathers initiated normally and induced a normal epithelial placode, suggesting that the action of the Eph/ ephrin pathway took place during later stages of morphogenesis. We previously provided evidence that the Turing reaction-diffusion model followed by chemotaxis was involved in aspects of early feather bud development (Jiang et al., 2004; Lin et al., 2009). In this model there are two classes of molecules: activators and inhibitors. Activators promote feather formation while inhibitors block their formation. However, in our current study, we found that after

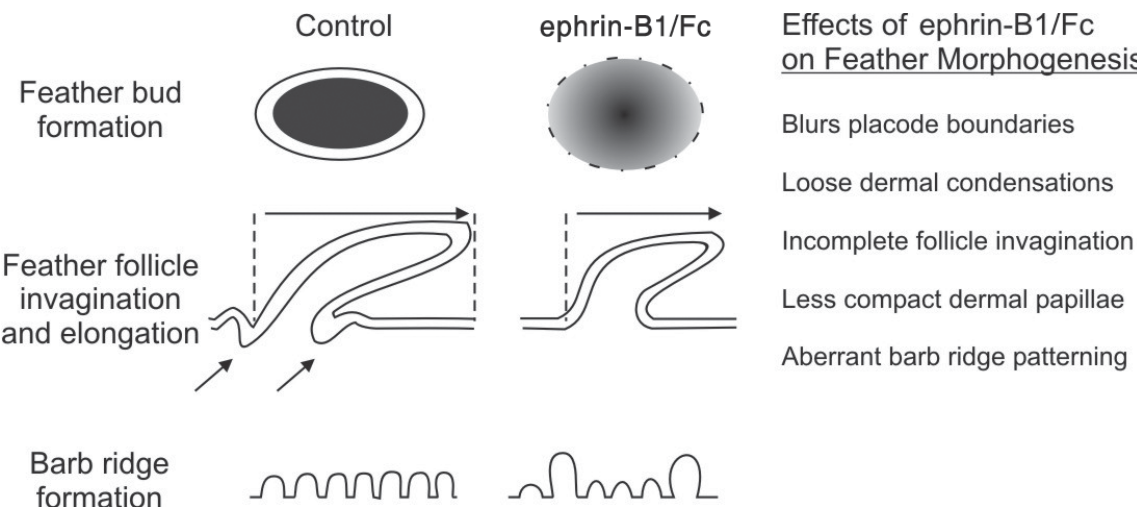

\section{Control}

$\begin{gathered}\text { Feather bud } \\ \text { formation }\end{gathered}$
$\begin{gathered}\text { Feather follicle } \\ \text { invagination } \\ \text { and elongation }\end{gathered}$
Barb ridge
formation

Fig. 6. Schematic showing roles of ephrin-B1 signaling. Ephrin-B1 signaling is involved in consolidating feather bud formation, feather follicle invagination and elongation, and in barb ridge formation. 
bud initiation the bud-interbud boundaries must be stabilized in order for normal feather morphogenesis to occur. When ephrin-B1 mediated stabilization was blocked, feathers grew wider and did not elongate properly. They also did not form normal barb ridges that are required for branching morphogenesis that is the hallmark of their function.

Interactions between signal transduction, cell migration and adhesion have been implicated in epithelial bud formation during skin organogenesis (Jamora et al., 2003). Establishing a foundation at the base of the feather may be a key step in regulating the feather size and enabling the feather to elongate properly. Here we propose that a signaling network, the Eph/ephrin pathway is essential to consolidate normal feather bud formation. In particular, inhibition of ephrin-B1 caused the dermal cells to remain diffuse which led to the formation of incomplete dermal condensations. Later in development the buds had a wider base and were unable to invaginate properly into the underlying dermis. We interpret this as evidence that an incomplete boundary was established between cells within the feather buds and those in the interbud zone when Eph/ephrin signaling is suppressed. Later in development, barb ridges in ephrin-B1/Fc treated skin explants failed to establish their normal order. Rather the barb ridges varied in size and their cells lacked the precise organization seen in normal feather buds. Due to the promiscuity of binding between Eph receptors and their ephrin ligands, it was difficult to pinpoint which Eph receptor is responsible for these observations; however the data do suggest that ephrin-B1 is essential for epithelial rearrangements necessary for dermal condensation, follicle invagination and later barb ridge formation. Together, these data suggest that bidirectional signaling involving ephrin-B1 is required for the proper progression of later stage feather development; possibly to stabilize dermal condensations and feather bud boundaries.

\section{Materials and Methods}

\section{Immunohistochemistry and in situ hybridization}

Chicken embryos were staged according to $\mathrm{H} \& \mathrm{H}$ staging (Hamburger and Hamilton, 1951). The whole mount in situ protocol was performed as described (Jiang et al., 1998). For sections, fixed embryos were embedded in paraffin and sectioned at 5-6 $\mu \mathrm{m}$. After de-paraffinization, sections were stained for $\mathrm{H} \& \mathrm{E}$, subjected to in situ hybridization or immunohistochemistry (Chang et al., 2004b). Blocking solution contained 10\% FBS/ 0.5\% BSA in PBS. Antibody dilution solution contained $2 \% \mathrm{FBS} / 0.1 \%$ BSA. Some section in situ hybridization was performed using the automated Discovery ${ }^{\mathrm{TM}}$ system (Ventana Medical System) with recommended protocols. The antibodies used were anti-ephrin-B1 (gift from Dr. Pasquale, Burnham Institute), or anti-ephrin-B1 anti-ephrin-A2 and anti-ephrin-A4 (R\&D, Minneapolis), anti-LCAM, anti-NCAM (Chuong and Edelman, 1985), anti-fibronectin, and anti-Tenascin-C (M1B4) (Developmental Studies Hybridoma Bank developed under the auspices of the NICHD and maintained by the University of lowa, Department of Biological Sciences, lowa City, IA 52242), PCNA (Chemicon, Temecula, CA). Finally, Alk-P secondary antibodies were added, and substrates of Alk-P were used to visualize the molecular localization. In some cases, we used Streptavidin-Cy3 to visualize the signal.

\section{Whole-mount immunofluorescent staining for explant cultures}

Cultured explants were fixed in $4: 1$ ratio of methanol: DMSO at $4^{\circ} \mathrm{C}$ for 16-18h. The skins were washed with PBT (Phosphate buffer saline and $0.1 \%$ Tween-20) three times, at $10 \mathrm{~min}$ each. Non-specific binding was then blocked with blocking solution (10\%FBS and $0.5 \% \mathrm{BSA})$. Antibodies were diluted in $2 \% \mathrm{FBS}$ and $0.1 \% \mathrm{BSA}$ and added at $4{ }^{\circ} \mathrm{C}$ for $16-18 \mathrm{~h}$. After washing, fluorescence-conjugated secondary antibody was added to visu- alize molecular localization. We then examine the results using confocal microscopy (Nikon), located in the microscopy core at the USC Center for Liver Diseases (NIH 1 P03 DK48522). Each time point was collected from at least 3 specimens.

\section{Perturbation with ephrin-B1/Fc in feather reconstitution assay}

Feather reconstitution assays were prepared according to Jiang et al., 1999. For perturbation, 1 to 200 mesenchymal cells were labeled with Dil before incubation with $10-20 \mathrm{ug} / \mathrm{ml}$ of ephrin-B1/Fc or $0.1 \%$ BSA as a control for an hour. Following reconstitution with an epithelial sheet, the feather explants were cultured with ephrin-B1/Fc (10-20 ug/ml) containing culture medium. Explants were harvested at designated time points and 3-5 specimens at each time point were collected.

\section{Density of mesenchymal cells}

Mesenchymal cell density was determined by staining tissues with propidium iodide and then counting the number of red nuclei within a constant sized window.

\section{Acknowledgements}

This research was supported by the NIAMS through grants AR 42177 (to CMC), AR 47364 (to CMC and RW) and AR 60306 (to CMC and TXJ). Sanong Suksaweang was supported by a Royal Thai Government Scholarship from Thailand. Confocal microscopy was performed by the Cell and Tissue Imaging Core of the USC Research Center for Liver Diseases, NIH grant No. P30 DK048522.

\section{References}

ALIBARDI, L. (2010a). Ultrastructure of the Feather Follicle in Relation to the Formation of the Rachis in Pennaceous Feathers. Anat Sci Int 85: 79-91.

ALIBARDI, L. (2010b). Gap and Tight Junctions in the Formation of Feather Branches: A Descriptive Ultrastructural Study. Ann Anat 192: 251-258.

ALIBARDI, L., TONI, M. (2008). Cytochemical and Molecular Characteristics of the Process of Cornification during Feather Morphogenesis. Prog Histochem Cytochem 43: 1-69.

ATIT, R., CONLON, R.A., NISWANDER, L. (2003). EGF Signaling Patterns the Feather Array by Promoting the Interbud Fate. Dev Cell 4: 231-240.

BATLLE, E., WILKINSON, D.G. (2012). Molecular Mechanisms of Cell Segregation and Boundary Formation in Development and Tumorigenesis. Cold Spring Harb Perspect Biol 4: 10.1101/cshperspect.a008227.

CHANG, C.H., JIANG, T.X., LIN, C.M., BURRUS, L.W., CHUONG, C.M., WIDELITZ, R. (2004a). Distinct Wnt Members Regulate the Hierarchical Morphogenesis of Skin Regions (Spinal Tract) and Individual Feathers. Mech Dev 121: 157-171.

CHANG, C.H., YU, M., WU, P., JIANG, T.X., YU, H.S., WIDELITZ, R.B., CHUONG C.M. (2004b). Sculpting Skin Appendages Out of Epidermal Layers Via Temporally and Spatially Regulated Apoptotic Events. J Invest Dermatol 122: 1348-1355.

CHODANKAR, R., CHANG, C.H., YUE, Z., JIANG, T.X., SUKSAWEANG, S., BURRUS, L., CHUONG, C.M., WIDELITZ, R. (2003). Shift of Localized Growth Zones Contributes to Skin Appendage Morphogenesis: Role of the Wnt/beta-Catenin Pathway. J Invest Dermatol 120: 20-26.

CHUONG, C.M. (2003). Homeobox Genes, Fetal Wound Healing, and Skin Regional Specificity. J Invest Dermatol 120: 9-11.

CHUONG, C.M., HOMBERGER, D.G. (2003). Development and Evolution of the Amniote Integument: Current Landscape and Future Horizon. J Exp Zoolog $B$ Mol Dev Evol 298: 1-11.

CHUONG, C.M., PATEL, N., LIN, J., JUNG, H.S., WIDELITZ, R.B. (2000). Sonic Hedgehog Signaling Pathway in Vertebrate Epithelial Appendage Morphogenesis: Perspectives in Development and Evolution. Cell Mol Life Sci 57: 1672-1681.

CHUONG, C.M., EDELMAN, G.M. (1985). Expression of Cell-Adhesion Molecules in Embryonic Induction. I. Morphogenesis of Nestling Feathers. J Cell Biol 101: 1009-1026.

COMPAGNI, A., LOGAN, M., KLEIN, R., ADAMS, R.H. (2003). Control of Skeletal Patterning by ephrinB1-EphB Interactions. Dev Cell 5: 217-230. 
COOKE, J.E., MOENS, C.B. (2002). Boundary Formation in the Hindbrain: Eph Only it were Simple. Trends Neurosci 25: 260-267.

COULTHARD, M.G., DUFFY, S., DOWN, M., EVANS, B., POWER, M., SMITH, F., STYLIANOU, C., KLEIKAMP, S., OATES, A., LACKMANN, M., BURNS, G.F., BOYD, A.W. (2002). The Role of the Eph-Ephrin Signalling System in the Regulation of Developmental Patterning. Int J Dev Biol 46: 375-384.

DAHMANN, C., OATES, A.C., BRAND, M. (2011). Boundary Formation and Maintenance in Tissue Development. Nat Rev Genet 12: 43-55.

DAVY, A., AUBIN, J., SORIANO, P. (2004). Ephrin-B1 Forward and Reverse Signaling are Required during Mouse Development. Genes Dev 18: 572-583.

DURBIN, L., BRENNAN, C., SHIOMI, K., COOKE, J., BARRIOS, A., SHANMUGALINGAM, S., GUTHRIE, B., LINDBERG, R., HOLDER, N. (1998). Eph Signaling is Required for Segmentation and Differentiation of the Somites. Genes Dev 12: 3096-3109.

EASTY, D.J., BENNETT, D.C. (2000). Protein Tyrosine Kinases in Malignant Melanoma. Melanoma Res 10: 401-411.

EGAWA, G., OSAWA, M., UEMURA, A., MIYACHI, Y., NISHIKAWA, S. (2009). Transient Expression of Ephrin b2 in Perinatal Skin is Required for Maintenance of Keratinocyte Homeostasis. J Invest Dermatol 129: 2386-2395.

GENANDER, M., FRISEN, J. (2010). Ephrins and Eph Receptors in Stem Cells and Cancer. Curr Opin Cell Biol 22: 611-616.

GUO, H., MIAO, H., GERBER, L., SINGH, J., DENNING, M.F., GILLIAM, A.C., WANG, B. (2006). Disruption of EphA2 Receptor Tyrosine Kinase Leads to Increased Susceptibility to Carcinogenesis in Mouse Skin. Cancer Res 66: 7050-7058.

HAFNER, C., SCHMITZ, G., MEYER, S., BATAILLE, F., HAU, P., LANGMANN, T., DIETMAIER, W., LANDTHALER, M., VOGT, T. (2004). Differential Gene Expression of Eph Receptors and Ephrins in Benign Human Tissues and Cancers. Clin Chem 50: 490-499.

HAMBURGER, V., HAMILTON, H.L. (1951). A Series of Normal Stages in the Development of the Chick Embryo. J Morphol 88: 49-92.

HARRIS, M.P., LINKHART, B.L., FALLON, J.F. (2004). Bmp7 Mediates Early Signaling Events during Induction of Chick Epidermal Organs. Dev Dyn 231: 22-32.

HARRIS, M.P., FALLON, J.F., PRUM, R.O. (2002). Shh-Bmp2 Signaling Module and the Evolutionary Origin and Diversification of Feathers. J Exp Zool 294: 160-176.

HESS, A.R., MARGARYAN, N.V., SEFTOR, E.A., HENDRIX, M.J. (2007). Deciphering the Signaling Events that Promote Melanoma Tumor Cell Vasculogenic Mimicry and their Link to Embryonic Vasculogenesis: Role of the Eph Receptors. Dev Dyn 236: 3283-3296.

HIRAI, H., MARU, Y., HAGIWARA, K., NISHIDA, J., TAKAKU, F. (1987). ANovel Putative Tyrosine Kinase Receptor Encoded by the Eph Gene. Science 238: 1717-1720.

HUGHES, M.W., WU, P., JIANG, T.X., LIN, S.J., DONG, C.Y., LI, A., HSIEH, F.J., WIDELITZ, R.B., CHUONG, C.M. (2011). In Search of the Golden Fleece: Unraveling Principles of Morphogenesis by Studying the Integrative Biology of Skin Appendages. Integr Biol (Camb). 3: 388-407.

JAMORA, C., DASGUPTA, R., KOCIENIEWSKI, P., FUCHS, E. (2003). Links between Signal Transduction, Transcription and Adhesion in Epithelial Bud Development. Nature 422: 317-322.

JANES, P.W., NIEVERGALL, E., LACKMANN, M. (2012). Concepts and Consequences of Eph Receptor Clustering. Semin Cell Dev Biol. 23: 43-50.

JIANG, T.X., TUAN, T.L., WU, P., WIDELITZ, R.B., CHUONG, C.M. (2011). From Buds to Follicles: Matrix Metalloproteinases in Developmental Tissue Remodeling during Feather Morphogenesis. Differentiation 81: 307-314.

JIANG, T.X., WIDELITZ, R.B., SHEN, W.M., WILL, P., WU, D.Y., LIN, C.M., JUNG, H.S., CHUONG, C.M. (2004). Integument Pattern Formation Involves Genetic and Epigenetic Controls: Feather Arrays Simulated by Digital Hormone Models. Int J Dev Biol 48: 117-135.

JIANG, T.X., JUNG, H.S., WIDELITZ, R.B., CHUONG, C.M. (1999). Self-Organization of Periodic Patterns by Dissociated Feather Mesenchymal Cells and the Regulation of Size, Number and Spacing of Primordia. Development 126: 4997-5009.

JIANG, T.X., CHUONG, C.M. (1992). Mechanism of Skin Morphogenesis. I. Analyses with Antibodies to Adhesion Molecules Tenascin, N-CAM, and Integrin. Dev Biol 150: 82-98.

JUNG, H.S., FRANCIS-WEST, P.H., WIDELITZ, R.B., JIANG, T.X., TING-BERRETH, S., TICKLE, C., WOLPERT, L., CHUONG, C.M. (1998). Local Inhibitory Action of BMPs and their Relationships with Activators in Feather Formation: Implications for Periodic Patterning. Dev Biol 196: 11-23.

KOO, B.K., LIM, H.S., CHANG, H.J., YOON, M.J., CHOI, Y., KONG, M.P., KIM, C.H., KIM, J.M., PARK, J.G., KONG, Y.Y. (2009). Notch Signaling Promotes the Generation of EphrinB1-Positive Intestinal Epithelial Cells. Gastroenterology 137: 145-155.

LIN, C.M., JIANG, T.X., BAKER, R.E., MAINI, P.K., WIDELITZ, R.B., CHUONG, C.M (2009). Spots and Stripes: Pleomorphic Patterning of Stem Cells Via p-ERKDependent Cell Chemotaxis shown by Feather Morphogenesis and Mathematical Simulation. Dev Biol 334: 369-382.

LUCAS, P. and STETTENHEIM, A. (1972). Avian anatomy. Integument. Agriculture Handbook. US Department of Agriculture, Washington, DC

MADERSON, P.F. (2004). Born in a Follicle--a Historical Perspective. Differentiation 72: 466-473.

MANDLER, M., NEUBUSER, A. (2004). FGF Signaling is Required for Initiation of Feather Placode Development. Development 131: 3333-3343.

MELLITZER, G., XU, Q., WILKINSON, D.G. (1999). Eph Receptors and Ephrins Restrict Cell Intermingling and Communication. Nature 400: 77-81.

MERRILL, A.E., BOCHUKOVA, E.G., BRUGGER, S.M., ISHII, M., PILZ, D.T., WALL, S.A., LYONS, K.M., WILKIE, A.O., MAXSON, R.E.,JR (2006). Cell Mixing at a Neural Crest-Mesoderm Boundary and Deficient Ephrin-Eph Signaling in the Pathogenesis of Craniosynostosis. Hum Mol Genet 15: 1319-1328.

MICHON, F., CHARVERON, M., DHOUAILLY, D. (2007). Dermal Condensation Formation in the Chick Embryo: Requirement for Integrin Engagement and Subsequent Stabilization by a Possible notch/integrin Interaction. Dev Dyn 236: 755-768.

NORAMLY, S., FREEMAN, A., MORGAN, B.A. (1999). Beta-Catenin Signaling can Initiate Feather Bud Development. Development 126: 3509-3521.

NORAMLY, S., MORGAN, B.A. (1998). BMPs Mediate Lateral Inhibition at Successive Stages in Feather Tract Development. Development 125: 3775-3787.

OLIVERA-MARTINEZ, I., THELU, J., TEILLET, M.A., DHOUAILLY, D. (2001). Dorsal Dermis Development Depends on a Signal from the Dorsal Neural Tube, which can be Substituted by Wnt-1. Mech Dev 100: 233-244.

PARK, E.C., CHO, G.S., KIM, G.H., CHOI, S.C., HAN, J.K. (2011). The Involvement of Eph-Ephrin Signaling in Tissue Separation and Convergence during Xenopus Gastrulation Movements. Dev Biol 350: 441-450.

PASQUALE, E.B. (2010). Eph Receptors and Ephrins in Cancer: Bidirectional Signalling and Beyond. Nat Rev Cancer 10: 165-180.

PASQUALE, E.B. (2005). Eph Receptor Signalling Casts a Wide Net on Cell Behaviour. Nat Rev Mol Cell Biol 6: 462-475.

PASSOS-BUENO, M.R., SERTI EACUTE, A.E., JEHEE, F.S., FANGANIELLO, R. YEH, E. (2008). Genetics of Craniosynostosis: Genes, Syndromes, Mutations and Genotype-Phenotype Correlations. Front Oral Biol 12: 107-143.

PATAN, S. (2004). Vasculogenesis and Angiogenesis. Cancer Treat Res 117: 3-32.

PITULESCU, M.E., ADAMS, R.H. (2010). Eph/ephrin Molecules - a Hub for Signaling and Endocytosis. Genes Dev 24: 2480-2492.

POLIAKOV, A., COTRINA, M., WILKINSON, D.G. (2004). Diverse Roles of Eph Receptors and Ephrins in the Regulation of Cell Migration and Tissue Assembly. Dev Cell 7: 465-480.

PRUM, R.O. (1999). Development and Evolutionary Origin of Feathers. J Exp Zool 285: 291-306

SANTIAGO, A., ERICKSON, C.A. (2002). Ephrin-B Ligands Play a Dual Role in the Control of Neural Crest Cell Migration. Development 129: 3621-3632.

SERRAS, F., FRASER, S., CHUONG, C.M. (1993). Asymmetric Patterns of Gap Junctional Communication in Developing Chicken Skin. Development 119: 85-96.

STOLFI, A., WAGNER, E., TALIAFERRO, J.M., CHOU, S., LEVINE, M. (2011). Neural Tube Patterning by Ephrin, FGF and Notch Signaling Relays. Development 138: 5429-5439.

TING, M.C., WU, N.L., ROYBAL, P.G., SUN, J., LIU, L., YEN, Y., MAXSON, R.E.,JR (2009). EphA4 as an Effector of Twist1 in the Guidance of Osteogenic Precursor Cells during Calvarial Bone Growth and in Craniosynostosis. Development 136: 855-864

TING-BERRETH, S.A., CHUONG, C.M. (1996a). Sonic Hedgehog in Feather Morphogenesis: Induction of Mesenchymal Condensation and Association with Cell Death. Dev Dyn 207: 157-170.

TING-BERRETH, S.A., CHUONG, C.M. (1996b). Local Delivery of TGF beta2 can Substitute for Placode Epithelium to Induce Mesenchymal Condensation during 


\section{S. Suksaweang et al.}

Skin Appendage Morphogenesis. Dev Biol 179: 347-359.

TUMBAR, T., GUASCH, G., GRECO, V., BLANPAIN, C., LOWRY, W.E., RENDL, M., FUCHS, E. (2004). Defining the Epithelial Stem Cell Niche in Skin. Science 303: 359-363.

TWIGG, S.R., KAN, R., BABBS, C., BOCHUKOVA, E.G., ROBERTSON, S.P., WALL, S.A., MORRISS-KAY, G.M., WILKIE, A.O. (2004). Mutations of Ephrin-B1 (EFNB1), a Marker of Tissue Boundary Formation, Cause Craniofrontonasal Syndrome. Proc Natl Acad Sci USA 101: 8652-8657.

VEARING, C., LEE, F.T., WIMMER-KLEIKAMP, S., SPIRKOSKA, V., TO, C., STYLIANOU, C., SPANEVELLO, M., BRECHBIEL, M., BOYD, A.W., SCOTT, A.M., LACKMANN, M. (2005). Concurrent Binding of Anti-EphA3 Antibody and Ephrin-A5 Amplifies EphA3 Signaling and Downstream Responses: Potential as EphA3-Specific Tumor-Targeting Reagents. Cancer Res 65: 6745-6754.

WESSELLS, N.K. (1965). Morphology and Proliferation during Early Feather Development. Dev Biol 12: 131-153.
WIDELITZ, R.B., JIANG, T.X., LU, J., CHUONG, C.M. (2000). Beta-Catenin in Epithelia Morphogenesis: Conversion of Part of Avian Foot Scales into Feather Buds with a Mutated Beta-Catenin. Dev Biol 219: 98-114.

WIDELITZ, R.B., JIANG, T.X., NOVEEN, A., CHEN, C.W., CHUONG, C.M. (1996). FGF Induces New Feather Buds from Developing Avian Skin. J Invest Dermatol 107: 797-803.

XU, Q., MELLITZER, G., ROBINSON, V., WILKINSON, D.G. (1999). In vivo Cell Sorting in Complementary Segmental Domains Mediated by Eph Receptors and Ephrins. Nature 399: 267-271.

YAMADA, Y., MIDORIKAWA, T., OURA, H., YOSHINO, T., OHDERA, M., KUBO, Y., ARASE, S. (2008). Ephrin-A3 Not Only Increases the Density of Hair Follicles but also Accelerates Anagen Development in Neonatal Mice. J Dermatol Sci 52: 178-185.

YU, M., WU, P., WIDELITZ, R.B., CHUONG, C.M. (2002). The Morphogenesis of Feathers. Nature 420: 308-312. 


\section{Further Related Reading, published previously in the Int. J. Dev. Biol.}

On the role of Eph signalling in thymus histogenesis; EphB2/B3 and the organizing of the thymic epithelial network Javier García-Ceca, Eva Jiménez, David Alfaro, Teresa Cejalvo, Michael J. Chumley, Mark Henkemeyer, Juan-José Muñoz and Agustín G. Zapata Int. J. Dev. Biol. (2009) 53: 971-982

Waves and patterning in developmental biology: vertebrate segmentation and feather bud formation as case studies

Ruth E. Baker, Santiago Schnell and Philip K. Maini

Int. J. Dev. Biol. (2009) 53: 783-794

\section{Skin field formation: morphogenetic events}

Danielle Dhouailly, Isabel Olivera-Martinez, Ingrid Fliniaux, Sylvain Missier, Jean P Viallet and Jacques Thélu

Int. J. Dev. Biol. (2004) 48: 85-91

The biology of feather follicles

Mingke Yu, Zhicao Yue, Ping Wu, Da-Yu Wu, Julie-Ann Mayer, Marcus Medina, Randall B Widelitz, Ting-Xin Jiang and Cheng-Ming Chuong

Int. J. Dev. Biol. (2004) 48: 181-191

Integument pattern formation involves genetic and epigenetic controls: feather arrays simulated by digital hormone models

Ting-Xin Jiang, Randall B Widelitz, Wei-Min Shen, Peter Will, Da-Yu Wu, Chih-Min Lin, HanSung Jung and Cheng-Ming Chuong

Int. J. Dev. Biol. (2004) 48: 117-135

$$
5 \text { yr ISI Impact Factor }(2011)=2.959
$$

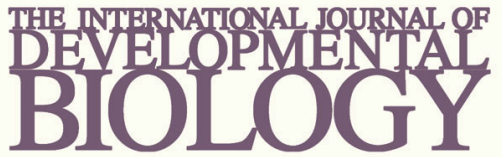

Volume 54 Nos. 6/7
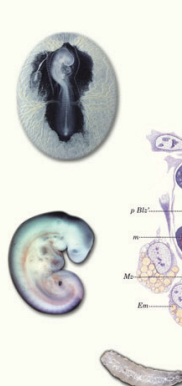

Developmental Hematopoiesis
Special Issue
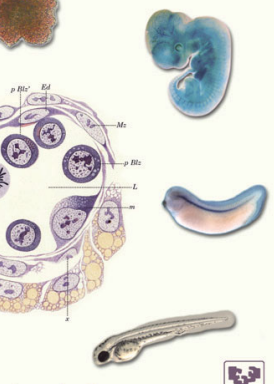

湾

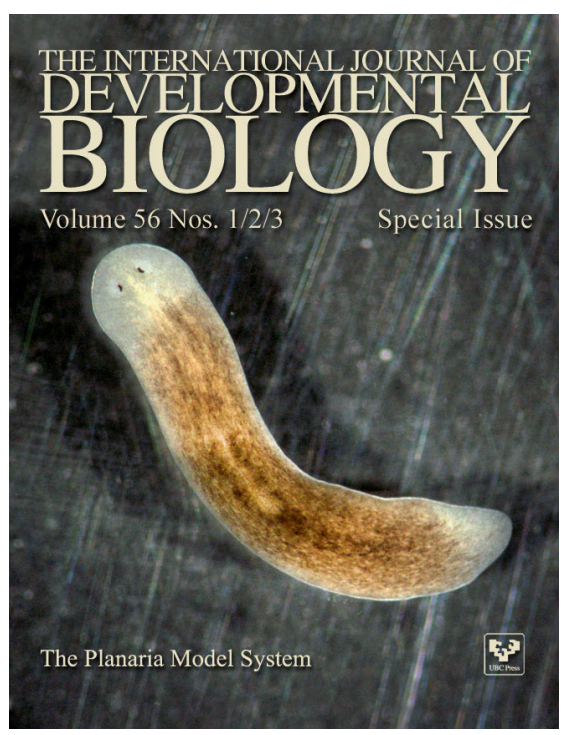

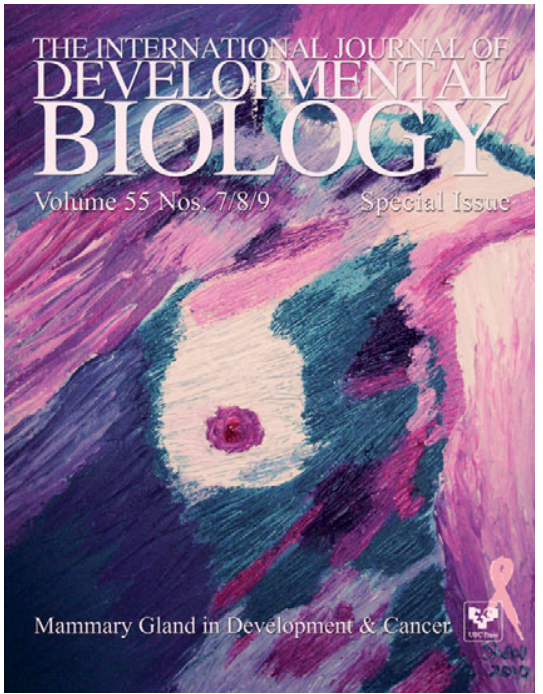

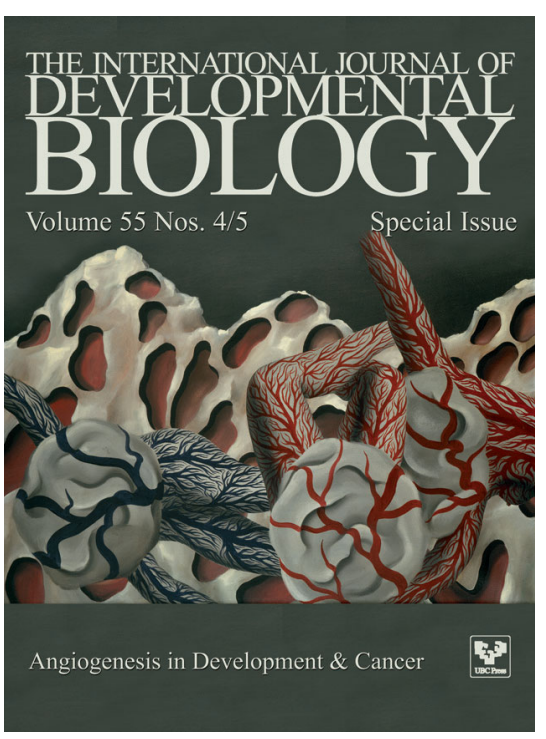

